\title{
Pandemic amplifies calls for alternative payment models
}

\author{
n Cite as: CMAJ 2020 June 8;192:E638-9. doi: 10.1503/cmaj.1095874
}

Posted on cmajnews.com on May 23, 2020

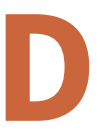

octors who depend on fee-forservice payments have seen their incomes drop considerably during the coronavirus disease 2019 (COVID-19) pandemic, while those paid under other models have been relatively unscathed. Now, some are calling for a permanent shift away from fee-for-service models to provide greater income security and support doctors providing care for complex patients.

The College of Family Physicians of Canada (CFPC) has long advocated for alternative payment models and recently reiterated the call. According to CFPC President Dr. Shirley Schipper, "the pandemic is exposing the structural shortcomings of fee-for-service models and the resulting uncertainty for community practices."

In Ontario, some doctors are petitioning the province to allow all primary care physicians to switch to a capitation model where groups of providers get a set amount of money per patient. As of May 22, the petition had more than 5000 signatures.

Dr. Nili Kaplan-Myrth, a family doctor in Ottawa and one of the 26 physicians who launched the petition, says her income is down by $30 \%$ to $50 \%$. She is seeing fewer patients but working harder than before the pandemic, logging up to 70 hours per week. She spends much of that time calling to check in with patients, especially those with new or worsening COVID-19 symptoms.

However, fee-for-service doctors "don't get paid a lot to have conversations," Kaplan-Myrth says. And higher-paying services, like pap tests and inserting intrauterine devices, aren't happening. Without that income, Kaplan-Myrth says she is barely able to cover her overhead expenses, including rent, medical equipment and payroll for her office staff.

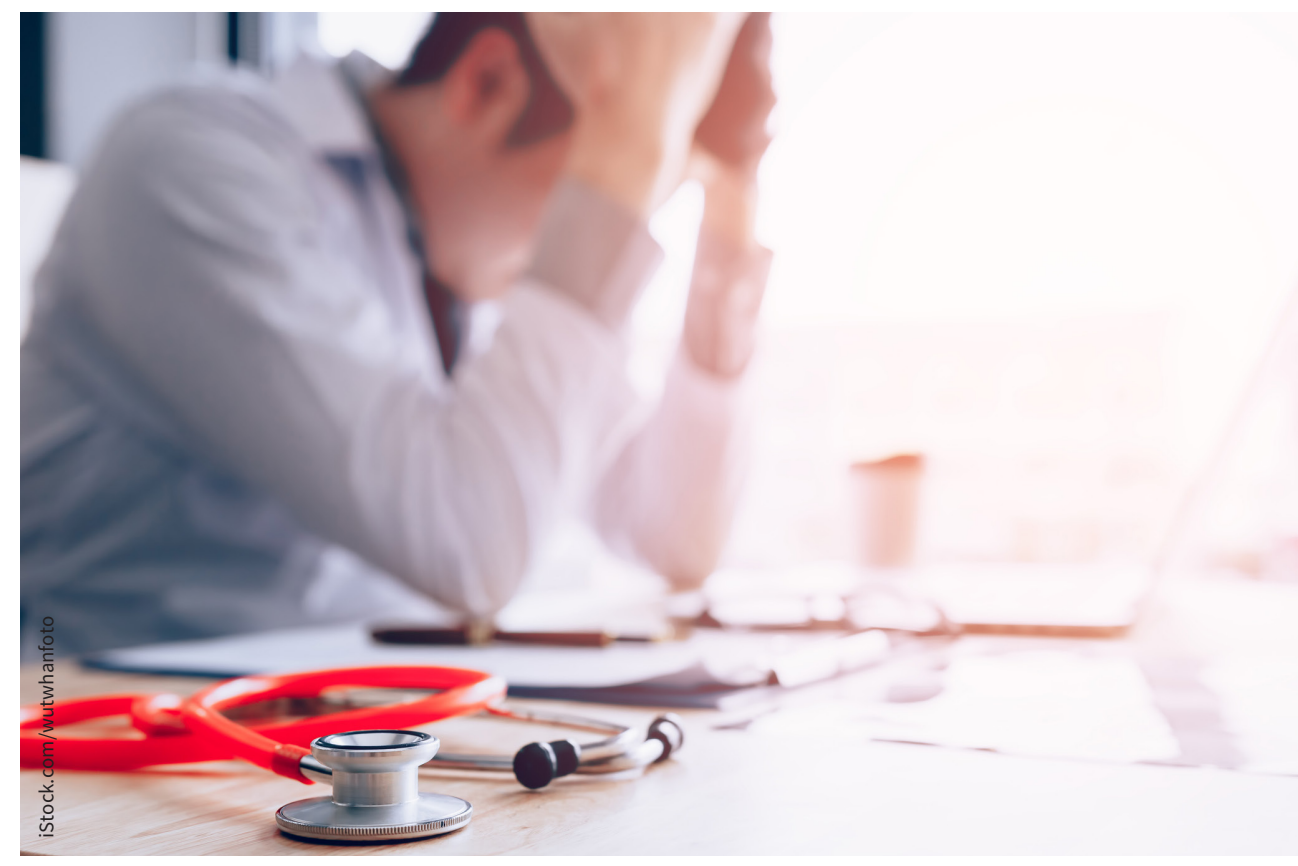

The slowdown in patients and procedures because of COVID-19 is hitting some doctors harder than others.

Kaplan-Myrth stresses that she didn't choose to work under the fee-for-service model. Her group tried to become a capitated "family health organization" just before the Ontario government limited the model to regions it deemed to be underserved.

On physician forums, she has seen other doctors talking about retiring early or abandoning their practices to work in groups with more stable payment models. Half of more than 4800 physicians surveyed by the Ontario Medical Association have already laid off staff, and $49 \%$ said they would have to close their practices unless they receive financial supports.

Doctors working under alternative payment models aren't feeling the same pinch. Dr. Patrick McDonald, head of pediatric neurosurgery at BC Children's
Hospital, says he and his colleagues in the department earn a fixed salary, so long as they meet their contract requirements. Surgeries are down by about half, partly because of delays for nonurgent procedures and because kids aren't engaging as much in activities that can lead to head trauma. But McDonald is paid the same. "We have essentially a guaranteed income," he says.

In rare cases, some salaried physicians are earning more while working less during the pandemic. Dr. Karim Vellani, one of 80 physicians working at the St. Michael's Family Health Team in Toronto, says he and his colleagues saw their incomes increase in the last two months, even though patients are booking fewer appointments.

Under Ontario's capitated "family health organization" model, doctors get an "access bonus" if their patients don't 
visit walk-in clinics. Normally, Vellani's team doesn't receive this bonus, but now their patients are avoiding walk-ins because of the pandemic. With the bonus, he is making about $7 \%$ more than usual.

Vellani argues that it doesn't make sense to pay bonuses to salaried doctors given the current crisis. "This money should have been temporarily taken out from capitated models during the pandemic and used to stabilize fee-forservice doctors," he says.

Patient volumes are down in almost every specialty, except a few outliers like intensive care, because patients are delaying care to avoid potential exposure to COVID-19. And health systems have delayed many procedures to free up resources for patients with COVID-19. "We see this huge divide now in terms of who is being adversely affected by the pandemic based on how they get paid," says Dr. Lesley Barron, a surgeon in Georgetown, Ontario.

Barron says that while she used to perform six surgeries on her busiest day of the week, that number is down to one or two. Her income dropped $50 \%$ in April, yet she's still paying overhead expenses. Meanwhile, procedures are taking much longer but pay at the same rates as before the pandemic. Barron says that a surgery that took one hour before takes three hours now. Resource shortages have created additional administrative work. There are long waits for aerosolized virus to clear after intubating and extubating patients. And because Barron is performing only urgent surgeries, the cases she sees are more complicated than usual.

As hospitals start to allow elective procedures again, "there is a risk that doctors will be motivated to do the higher paying, but less urgent procedures" to make up for lost income, Barron says. She argues that alternative payment models support better prioritization of patients.

Emergency physicians paid under feefor-service models are also seeing fewer, but more complex patients. "No one is coming in because of an ankle sprain," says Dr. Steve Flindall, an emergency physician at Mackenzie Richmond Hill Hospital in Ontario. Donning and doffing protective equipment can add an extra 20 minutes per patient, Flindall says. His income has dropped by a third, even though he's working more shifts than usual at both the emergency department and his hospital's COVID-19 clinic.

However, Flindall disagrees with a permanent move away from fee-forservice. "Previous reports have shown the government gets more bang for their buck with fee-for-service models," he says, explaining that doctors paid per service tend to see more patients in less time. Instead, Flindall would like to see provinces offer temporary income stabilization for fee-for-service doctors.

Some Atlantic provinces are taking steps to address inequalities in physician pay during the pandemic. In Nova Scotia, doctors who made less than $\$ 260000$ last year will get the same amount this year, while those who made more than $\$ 260000$ will receive up to $80 \%$ of their previous year's earnings. Newfoundland has a similar program, and $\mathrm{PEI}$ is compensating doctors who have lost money because of restrictions on elective procedures or because they needed to self-isolate.

According to Dr. Gary Ernest, president of Doctors Nova Scotia, about 7000 of the province's 12000 fee-for-service physicians have signed up for the stabilization program. To get the money, they must agree to be redeployed, if necessary, during the pandemic.

"The key principle here is taking away the worry about not being able to keep their offices going, of not being able to make mortgage payments, so when the time comes for all hands on deck, we'll have emotionally and physically healthy physicians," Ernest says.

So far, mandatory redeployments have not been necessary because enough doctors have volunteered to help with the testing and treatment of COVID-19 patients.

The additional income is a "huge relief," says Dr. Michael Mindrum, an internal medicine physician in Port Williams, Nova Scotia. "I think the public probably thinks a lot of doctors are swimming in money, but there are a lot of fixed overhead costs, and the margins aren't that big."

Wendy Glauser, Toronto, Ont. 